\title{
PRINSIP, KETENTUAN, DAN KARAKTERISTIK PEMBIAYAAN (BANK) SYARIAH
}

\author{
Hendy Herijanto
}

\begin{abstract}
The characteristics of Islamic financing must follow the governing Qur'anic verses and the Hadis of the Prophet Muhammad Puh. This means that the epistemology derives from the Tauhidi Principle, being different from the one of the conventional economy and banking that is deriving from the western culture and purely rational thinking. Their basic and main principles are for the creation of both, the individual and collective well being of the society, consisting of Tauhidi Principle, vicegerency, justice, and material and spiritual balances. These principles can be fulfilled by adhering to the Qur'anic stipulations, ie, emphasizing on trade and doing no ribawi transactions (QS. 2: 275), and working on cooperative basis (QS. 5: 2). These stipulations bring about a deep and wide significance and implication.

For creating the collective well being of the society, Islamic financing can only be implemented by using the existing contracts, without riba, non gharar, non maysir, aiming on non ribawi work results, common profit, using quasi equity and not purely money loan, risk sharing concept, being trustworthy, and keeping promises religiously. Consequently, money is put in its basic function that is as a medium of exchange and as a measure of the counter value being goods, services, and productive business in the real sector of the economy.
\end{abstract}

Key Words: Tauhidi principles, the well being of the society, non interest, non gharar, non maysir, goods and sevices, and trusworthy.

\section{A. Pendahuluan}

Berbeda dengan perkreditan bank konvensional, pembiayaan syariah merupakan bagian dari ekonomi Islam yang sarat dengan nilai atau value laden. Epistemologi ekonomi dan pembiayaan Islam adalah prinsip Tauhid atau Keesaan Tuhan. Karena ekonomi Islam merupakan kegiatan yang berkaitan dengan hubungan antara sesama manusia -muammalah- maka pembiayaan 
Islam juga harus mengacu kepada ketentuan bermuammalah yang ada dalam Alqur'an sebagai kalam Allah, dan Hadis Nabi Muhammad saw. Oleh karena itu, kegiatan ekonomi dan pembiayaan (bank) mencakup unsur etika dan moralitas, yaitu mencapai kebahagiaan duniawi dan ukhrawi serta untuk mencapai kemaslahatan atau kesejahteraan bersama dalam masyarakat. Epistemologi ekonomi dan perkreditan konvensional, di lain pihak, bersumber pada kebudayaan dan pemikiran manusia di bagian barat dunia.

Tulisan ini bertujuan untuk menguraikan secara ringkas mengenai hal ikhwal ekonomi Islam, terutama mengenai prinsip dasar dan prinsip pokoknya, yang juga merupakan dasar bagi pembiayaan Islam. Tulisan ini lebih lanjut menguraikan secara ringkas mengenai ketentuan utama yang mendasari pembiayaan Islam. Berdasarkan prinsip-prinsip dan ketentuan yang dimaksud, dapat diuraikan karakteristik dari pembiayaan Islam.

\section{B. Prinsip dan Ketentuan yang Mengatur}

Kegiatan pembiayaan (bank) syariah atau Islam adalah sub sektor dari ekonomi Islam, yang diartikan sebagai ekonomi yang berketuhanan, bertitik tolak dari Allah dan bertujuan akhir kepada Allah, serta menggunakan sarana yang tidak lepas dari syariat Islam (Qardhawi, 1997: 31). Di dalamnya, terdapat tiga kata terkait erat satu sama lain, yaitu kehidupan, manusia dan Tuhan (Agil dan Ghazali, 2005: 81).

\section{a. Prinsip Dasar: Rahmat Bagi Sekalian Alam}

Salah satu ayat yang paling penting bagi kehidupan manusia dan bersifat sangat filosofis dan aplikatif adalah yang berbunyi, "Kami tidak mengutus engkau (Muhammad) melainkan untuk (menjadi) rahmat bagi seluruh alam (rahmatan lil 'älamīn)" (QS. 21: 107). Hal ini sejalan dengan pengertian "Rahmatan lil 'ālamīn", yang merupakan tugas utama Nabi Muhammad saw. sebagai Rasul Allah. Hal ini menjadi prinsip dasar yang berlaku bagi seluruh umat manusia agar bertindak sebagai pemakmur (QS. 11: 61) bagi sekalian ciptaan Tuhan, termasuk seluruh umat manusia, tumbuh-tumbuhan, dan hewan (Al-Qarny, 2010: 84), serta alam semesta atau lingkungan hidup manusia. Bagi Islam, manusia yang beriman merupakan wakil Allah SWT. di dunia untuk menjalankan kebajikan dan menghindari kerusakan, "amar ma'rüf nahy munkar". Makna rahmatan lil 'älamīn sejalan dengan pengertian maqāsid al syarì'ah, yang intinya menciptakan kemaslahatan atau al-silah dan menghindari kemudharatan atau kerusakan. Jadi, tugas manusia di dunia adalah untuk menciptakan kemaslahatan bagi seluruh manusia dan segala ciptaaan Tuhan dan menghindari kerusakkan. 


\section{b. Prinsip Pokok}

Seluruh kegiatan manusia harus mengacu kepada 4 prinsip pokok, yaitu Tawhìd (unity atau Keesaan Tuhan), Khiläfah (vicegerency atau wakil) dan 'Adālah (justice atau keadilan), dan Taskiyah (keseimbangan material dan spiritual).

\section{c. Ketentuan Utama}

Ketentuan utama yang mengatur mengenai pembiayaan Islam adalah: Pertama, Surah Al-Baqarah (QS. 2: 275), yang antara lain menyebutkan, "Allah telah menghalalkan jual beli dan mengharamkan riba". Kedua, Surah AlMā'idah (QS. 5: 2) yang berbunyi, "Dan tolong menolonglah kamu dalam (mengerjakan) kebajikan dan taqwa, dan jangan tolong menolong dalam berbuat dosa dan pelanggaran.....". Di samping itu, ketentuan bermuamalah, atau dalam hubungan antar sesama manusia, atau berdagang, adalah diijinkan sejauh tidak ada ketentuan yang melarangnya. Bank syariah harus memperhatikan larangan tersebut. Transaksi tidak boleh mengandung riba, gharar, dan maysir, di samping dilarang membiayai barang atau jasa yang diharamkan. Pemilihan kata dalam Alqur'an diyakini sangat efisien dan efektif, dan tidak akan pernah dirubah. Maknanya berlaku sepanjang zaman dan di setiap waktu dan tempat, maka implikasi dari makna kedua kata 'berdagang', 'riba' dan 'tolong menolong dalam kebajikan' dapat menjadi luas.

\section{Karakteristik Pembiayaan Syariah}

\section{a. Non Ribawi: Pendapatan yang setara dengan hasil kerja}

Secara umum, riba dimengerti sebagai tambahan yang diberikan atas pinjaman uang, atau disebut bunga. Dalam arti lain, riba dapat timbul karena pertukaran barang atau barter yang tidak sepadan, baik dalam takaran, timbangan, ataupun kualitas barang. Dalam pertukaran barang yang sejenis, seperti emas dengan emas, perbedaan kadarnya tidak bisa diukur dengan akurat, atau tidak serta merta dapat diketahui; di sini, tambahan tidak diperbolehkan. Tetapi, tambahan pada pertukaran barang dengan jenis yang berbeda, seperti kurma dengan gandum, diijinkan; tambahan di sini berfungsi sebagai penyeimbang dari perbedaan nilai dari kedua barang. Dari pertukaran seperti ini, dapat disimpulkan bahwa setiap pihak dalam transaksi itu jelas mengetahui dan menyadari perbedaan barang yang ditukarkan, sekaligus dapat mengukur tambahan yang seimbang. Pada dasarnya, pertukaran atau jual beli dengan counter value yang tidak seimbang adalah juga riba. 
Hadis Nabi saw yang diriwayatkan oleh HR Abu Dawud dan HR Baihaki menyatakan bahwa ketidakjujuran atau penipuan penjual terhadap pembeli adalah termasuk perbuatan ribawi. Nabi saw juga bersabda bahwa memakan harta orang lain tanpa jerih payah dan risiko merupakan tindakan ribawi, bahkan disetarakan dengan penyakit masyarakat seperti menjual kehormatan. Alqur'an menyebutkan bahwa memakan harta benda orang dengan jalan yang bathil adalah riba (QS. 4: 161). Menurut Abu Zaid (2010), makna qiyas terhadap kata riba itu adalah memakan harta orang lain dengan cara yang tidak benar.

Salah satu akibat dari riba adalah mendorong orang untuk memperoleh hasil yang instan tanpa bekerja, sehingga menjadi malas atau tidak produktif. Itulah sebabnya Allah SWT telah menghalalkan perdagangan, dan mengharamkan riba, walaupun pada dasarnya perdagangan dan riba serupa, dalam hal memperoleh keuntungan bagi yang pertama dan tambahan bagi yang kedua. Namun, implikasi perdagangan jauh lebih positif dan luas. Perdagangan adalah hilir dan hulu dari kegiatan produksi; apabila meningkat, akan mendorong produksi barang dan jasa yang lebih banyak. Produksi yang bertambah membuka lapangan kerja, dan menciptakan kesejahteraan umat. Keuntungan adalah panen dari kerja dan usaha di ladang produksi dan perdagangan, dan merupakan manifestasi kerja, usaha, dan risiko, sehingga tidak dapat diperoleh secara instan. Oleh karena itu, Ibnu Chaldun mengatakan bahwa kekayaan suatu negara terletak pada berapa banyak barang dan jasa yang dihasilkannya, bukan pada jumlah uang yang dimilikinya.

Jadi, peminjaman uang dengan tambahan, pertukaran yang tidak seimbang dalam takaran dan timbangan serta kadar barang, atau transaksi pertukaran dengan counter value yang tidak sepadan, atau tambahan yang diperoleh tanpa kerja, usaha, atau risiko, tidak produktif, atau memakan harta orang dengan cara yang bathil, merupakan transaksi ribawi. Semua hal ini tidak berujung pada peningkatan produksi barang dan jasa, yang dapat memberikan lapangan kerja produktif bagi umat; serta tidak mendorong terciptanya nilai-nilai kebajikan, seperti keadilan dan kejujuran. Pembiayaan Islam tidak terlepas dari tema kerja, produksi barang dan jasa, mengembangkan usaha, tidak bersifat ribawi, dan untuk kemasalahatan bersama.

\section{b. Fungsi Uang Sebagai Penyetara Nilai}

\section{Uang Merupakan Cerminan dari Barang}

Dalam Islam, uang berfungsi sebagai medium of exchange. Uang hanya merupakan sarana untuk mencapai suatu tujuan tetapi bukan merupakan tujuan itu sendiri (El-Diwany, 2003: 220). Al Ghazali, seperti yang dikutip oleh Habib 
Shirazi, menjelaskan uang sebagai "an 'intermediary' between assets, and works 'like a mirror', and only reflects the value of goods...". Dia juga mengatakan, "Money should not be created just because its very existence should create demand for it, but rather it should be used for the procurement of other goods..." (Shirazi, 1988: 39). Uang adalah nilai pembanding terhadap nilai barang atau jasa yang dipertukarkan; menandingi counter value.

Kutipan di atas jelas menunjukkan bahwa uang bukanlah alat produksi yang menghasilkan barang dan jasa, tetapi hanya merupakan alat ukur terhadap nilai dari barang dan jasa, atau hasil kerja. Hanya produksi barang dan jasa yang meningkat dapat membuka lapangan kerja, sehingga setiap anggota masyarakat mendapat peluang yang sama untuk bekerja. Semakin banyak anggota masyarakat yang bekerja, semakin meningkat tingkat kesejahteraan masyarakat. Ini adalah tema sentral dari ekonomi dan pembiayaan Islam, yang sejalan dengan maqasid al syariah dan Prinsip Dasar 'Rahmatan lil alamin'.

\section{Uang bukan sebagai komoditas dengan harga berupa bunga}

Jika uang ${ }^{1}$ diperlakukan sebagai komoditas maka akan menjurus pada transaksi ribawi (Marthon, 2004: 33). Karena tambahan atas uang ketika dipinjamkan dilarang, ini artinya bahwa uang tidak dapat diperdagangkan, atau memiliki harga, seperti bunga. Vogel (1998: 2) mengatakan bahwa, "(In Islam) Money is not treated as a commodity, as in the West...". Uang bukan sebagai komoditi, maka perbankan syariah tidak mengenal pinjam-meminjam uang dalam transaksi komersial atau tijarahnya. Pengertian ini berlaku sebagai dasar pembiayaan syariah.

Karena uang berfungsi terutama sebagai medium of exchange, dan penyetara nilai terhadap counter value seperti halnya dalam pertukaran atau jual beli, pembiayaan syariah harus didahului dengan transaksi yang memiliki counter value itu. Counter value ini merupaka nilai yang diperlukan untuk membiayai jual beli barang, penyewaan barang, atau untuk membiayai suatu usaha di sektor riel.

Dengan demikian, uang tidak berjalan sendiri, tanpa ada kaitan dengan barang, jasa atau usaha. Esensi yang penting dalam pembiayaan syariah bukan

${ }^{1}$ Menurut Al-Gazali, fungsi utama uang adalah sebagai alat tukar yang merefleksikan nilai sebuah komoditas, uang ibarat cermin yang tidak berwarna tetapi dapat merefleksikan semua warna. Abu Bakar Siddiq menjelaskan dalam sistem ekonomi Islam, uang mempunyai fungsi sebagai standar nilai dan satuan hitung, alat pembayaran, alat menyimpan kekayaan dan bukan sebagai penimbun kekayaan, dan sebagai alat pembayaran zakat dan kewajiban lainnya (Said Sa'ad Marthon, p 117). 
pinjam meminjam uang, yang menimbulkan utang dan berasal hanya dari peminjaman uang.

\section{Uang Merupakan Potensi Modal}

Aristoteles tidak menyetujui kegiatan pemberian pinjaman dikenakan bunga, karena tidak bersifat alami dan melanggar kebajikan (Green, 2009: 68). Uang pada dirinya sendiri tidak memiliki kemampuan untuk menciptakan apaapa, atau tidak dapat beranak; sehingga tidak memiliki produktivitas. Karena tidak dapat menghasilkan apa-apa, maka tidak dapat memperoleh kompensasi. Uang juga bukan langsung berarti modal karena uang hanya berpotensi untuk menjadi modal; dalam Islam, modal dikenal sebagai salah satu faktor produksi (DiVanna, 2008: 28).

Supaya menjadi modal, uang dikonversi terlebih dahulu menjadi salah satu faktor, dan digabungkan dengan faktor produksi yang lain agar produktif, sehingga menghasilkan barang dan jasa, menimbulkan perdagangan, menghasilkan pendapatan dan keuntungan, menciptakan lapangan kerja, dan akhirnya meningkatkan kemaslahatan masyarakat.

\section{Uang Endogen Islami Menekan inflasi}

Islam menggunakan uang terutama sebagai alat tukar atau sarana, bukan sebagai komoditi seperti yang dianut oleh kaum kapitalis; dan uang bukan merupakan tujuan itu sendiri (El-Diwany, 2003: 220). Sejalan dengan hal ini, motif permintaan akan uang adalah untuk memenuhi kebutuhan bertransaksi (Arifin, 2005: 16), atau dalam bahasa Keynes untuk bertransaksi dan berjagajaga (Toutounchian, 2009: 69); tetapi dalam Islam, tidak untuk berspekulasi. Transaksi yang bersifat spekulatif dilarang dalam Islam. Islam menggunakan teori uang endogen atau endogenous money yang berbeda.

Menurut Shakespeare (2007: 117-128), endogen berarti datang atau berkembang dari dalam, atau berasal atau diproduksi di dalam suatu organisme, tisu atau sel. Dalam ekonomi konvensional, uang endogen adalah uang yang berbunga berasal dari bank sentral sebagai asal organisme yang dimaksud; kemudian mengalokasikannya secara efektif untuk menciptakan pertumbuhan. Tetapi, Shakespeare menganggap pandangan ini sebagai justifikasi ekonomi neo klaisik yang tidak tepat, karena: pertama, bank komersial bukan merupakan pusat dari masyarakat, sehingga tidak mengherankan jika bank sentral tidak memiliki moralitas berupa kewajiban terhadap masyarakat; kedua, uang endogen konvensional tidak mengalokasikan sumber daya secara efisien, tetapi mendorong harga-harga aset naik, dan membuat dunia tetap memiliki utang yang terus bertambah, sehingga jumlah keseluruhan internal dan eksternal 
melebihi jumlah uang yang ada; ketiga, uang yang berbunga itu memiliki efek yang merusak. Di mana pun ada riba, akan merusak orang, perusahaan, kota, bangsa, dan perekonomian, yang mendorong dunia menuju bencana lingkungan.

Oleh karena itu, Shakespeare (2007: 125) memberikan definisi uang endogen yang lain, yaitu: pinjaman tanpa bunga yang berasal dari bank sentral dan diberikan kepada pemerintah untuk modal proyek lingkungan pemerintah atau publik. Proyek semacam ini dapat pula dimiliki oleh swasta, atau dikelola oleh sistem perbankan, atau dikeluarkan untuk sektor swasta, atau untuk memulai bisnis baru, termasuk untuk perusahaan besar dan menengah, jika kepemilikan modal diperluas. Pinjaman tanpa bunga untuk keperluan publik semacam ini telah digunakan di masa lalu, misalnya, pada proyek-proyek di Channel Island, Guernsey, proyek konstruksi di Malaysia, dan skim hydropower di New Zealand (Shakespeare, 2007: 126).

Menurut Choudhury (1997), di lain pihak, dalam Islam, pengertian uang endogen adalah sebagai berikut. Pada masa Nabi Besar Muhammad Saw, emas dan perak digunakan sebagai standar nilai uang. Sejalan dengan perintah Tuhan dan Hadis Nabi, pemecahan nilai uang emas dan perak ke dalam nilai yang lebih rendah sangat dilarang (Choudhury, 1997: 7). Pemecahan itu dapat terjadi karena timbulnya kekurangan atau kelebihan penawaran. Kondisi ini dapat timbul karena ketidak stabilan akibat dari tingkat bunga dan ketidak pastian, adanya spekulasi, atau penggunaan modal yang fisibilitasnya tidak dapat diukur dengan ukuran yang biasa digunakan dalam sektor riel (Choudhury, 1997: 7).

Oleh karena itu, Choudhury menyimpulkan bahwa sifat uang endogen dalam Islam adalah seperti yang dimaksud oleh Nabi Saw, yaitu menggunakan emas dan perak untuk keperluan transaksi pasar. Dalam hal ini, mata uang diciptakan sebagai perantara untuk memberikan nilai bagi harga-harga komoditas, atau barang dan jasa (Choudhury, 1997: 39). Menurut beliau lebih lanjut, teori uang endogen adalah $\mathrm{Md}=\mathrm{Ms}=\mathrm{M}(\mathrm{X}, \mathrm{Y}, \mathrm{O})$ (Choudhury, 1997: $41)^{2}$. Md adalah tingkat pengeluaran dalam ekonomi politik Islam. Ms merupakan penawaran uang, dan mewakili penyediaan mata uang dalam logam berharga untuk memenuhi keperluan pengeluaran. Ini artinya Ms meuangkan

${ }^{2} \mathrm{M}$ adalah jumlah uang yang diperlukan dan ditentukan oleh $\mathrm{X}, \mathrm{Y}, \Theta . \mathrm{X}=$ variabel sosio ekonomi, $Y=$ variabel kebijakan, dan $\Theta=$ variabel pengetahuan; teori uang endogen adalah juga $\mathrm{X}=\mathrm{x}(\mathrm{p})(\Theta), \mathrm{p}$ merupakan tingkat harga yang berkaitan dengan variabel sosio ekonomi $\mathrm{x}$, dan nilai $x$ dan $p$ dipengaruhi oleh $\Theta$. Keadaan $X=x(p)(\Theta)$ yang tergantung pada fungsi tingkat keuntungan $(p)(\Theta)$ mempengaruhi permintaan akan uang sebagai penggerak pengeluaran dan pertukaran (Choudhury, 1997: 41). 
harga-harga, atau monetizes prices" (Choudhury, 1997: 41). Dalam definisi konvensional, seperti yang telah disebutkan di atas, uang endogen didefinsikan sebagai uang yang berbunga dan berasal dari bank sentral. Di lain pihak, Islam mendefinisikannya sebagai mata uang dalam bentuk logam berharga; dan signifikasinya adalah bahwa uang endogen mewakili nilai emas dan perak, atau didukung oleh keduanya.

Pada hakikatnya, uang endogen berarti permintaan uang merupakan representasi dari seluruh kebutuhan transaksi dalam sektor riel (Choudhury, 1997: 14; Suprayitno, 2005: 209). Permintaan akan uang meningkat, jika kapasitas dan volume sektor riel meningkat. Choudhury (1997: 14) menjelaskan bahwa uang yang beredar hanya setara dengan yang dibutuhkan untuk bertransaksi di sektor riel, seperti yang digambarkan oleh persamaan Irving Fischer, yaitu $\mathrm{m} . \mathrm{v}=$ p. q. Uang yang beredar dikalikan dengan tingkat perputaran uang atau velocity of money harus setara dengan nilai barang dan jasa yang dihasilkan oleh suatu masyarakat negara. Uang yang beredar dapat dikontrol oleh bank sentral suatu negara. Teori ini tidak mendikotomikan antara pertumbuhan uang di sektor moneter dan pertumbuhan nilai tambah uang di sektor riel (Suprayitno, 2005: 209).

Di samping itu, perbankan Islam tidak mengenal penciptaan kredit atau credit creation seperti dalam bank konvensional, sehingga uang yang beredar dibatasi sebanyak yang diciptakan bank sentral. Dalam perbankan Islam, dana pihak ketiga atau deposit masyarakat dalam giro, tabungan, dan deposito bukanlah merupakan utang bagi bank; tetapi, berfungsi sebagai titipan dengan akad wadiah, dan berupa dana investasi dengan akad mudharabah. Dana investasi sepenuhnya disalurkan untuk investasi dengan nasabah bank lainnya, sehingga menekan terciptanya uang lewat kredit, yang berbeda dengan bank konvensional dengan fractional reserve banking-nya. Karena dana dalam akad wadiah hanya merupakan titipan, dan bank tidak dapat mempergunakannya, sehingga hanya disimpan di dalam reserve secara keseluruhan, maka bank Islam juga disebut sebagai $100 \%$ reserve banking.

Uang endogen yang dimaksud oleh Choudhury (1997), dan digambarkan oleh persamaan Irving Fischer pada hakikatnya menghindari pertumbuhan uang yang beredar melebihi nilai produksi barang dan jasa, atau pertumbuhan sektor riel. Inflasi terjadi, jika uang yang beredar lebih besar dari yang diperlukan untuk transaksi di sektor riel. Inflasi menurunkan daya beli, dan menegatifkan kemaslahatan masyarakat, yang bertentangan dengan maqasid al syariah.

\section{Keuntungan Pengganti Riba}


Karena riba dilarang, penggantinya adalah 'keuntungan'. Berbeda dengan riba, yang bersifat tetap, keuntungan bersifat variatif dan dapat lebih besar dari riba, karena sangat tergantung pada kemampuan dalam berusaha. Jadi, keuntungan pada dirinya dapat memberikan upside potential. Oleh karena itu, Toutounchian (2009: 331) berpendapat bahwa hal tersebut merupakan salah satu faktor yang dapat membantu pemerataan distribusi pendapat, dan merupakan kondisi yang diperlukan untuk pertumbuhan yang berkelanjutan atau sustained growth.

Banyak ayat Alqur'an menyebutkan mengenai 'keuntungan'. Salah satu ayat menyatakan bahwa perolehan keuntungan dari perniagaan adalah halal. Tuhan berfirman kepada orang-orang beriman agar berjalan dan berdagang dengan cara yang saling menguntungkan (QS. 4: 33). Dalam perspektif itu, keuntungan tidak dilihat dari segi uang secara an sich. Menurut Aa Gym dan Kartajaya (2004), 'keuntungan' bisnis adalah apabila bisnis yang dilakukan itu bersifat amal atau kebajikan, atau yang didasarkan pada kebenaran, yang dimulai dengan niat yang benar; dalam melakukan bisnis itu, kualitas manusianya semakin baik atau dapat lebih dipercaya, dapat menambah ilmu dan wawasan yang lebih luas sehingga memperbaiki kemampuan yang ada, dan menambah silahturahmi atau persaudaraan antara sesama.

Keuntungan pada dasarnya dihasilkan dari kombinasi usaha atau kerja, modal dan risiko; modal diartikan sebagai barang dagangan atau faktor produksi, sedangkan uang merupakan potensi modal yang dapat dikonversi ke dalam salah satu atau keduanya. Ellsworth (2010: 143) berpendapat bahwa keuntungan memiliki banyak fungsi, yaitu meliputi: memberikan kemampuan bagi perusahaaan atau usaha dalam rangka menciptakan manfaat bagi masyarakat, merupakan ukuran dari efektivitas dan efisiensi dalam melakukan manfaat itu, sebagai dasar bagi manajemen dalam mengambil keputusan, sebagai panduan untuk menciptakan nilai, dan seterusnya. Namun, Ellsworth mengingatkan bahwa keuntungan bukan merupakan tujuan akhir, tetapi sebagai alat untuk mencapai tujuan lain seperti posisi strategis perusahaan; sehingga tidak dimaksimalkan dalam arti yang sempit. Pandangan yang sempit terhadap maksimalisasi keuntungan adalah karena hanya berdasarkan dari segi pertimbangan materialistik dan bertumpu pada kepentingan pemegang saham semata. Agaknya pandangan yang sempit ini merupakan pendorong dari konsep maksimalisasi keuntungan yang disuarakan oleh Milton Friedman, sehingga menjadi isu yang berkaitan dengan masalah moralitas. Hal ini pula yang mungkin membuat Aristoteles berpandangan bahwa kegiatan "commerce" itu 
merupakan kegiatan yang lebih rendah sifatnya dari "politics" atau "philosophy", di samping mungkin bahwa kedua konsep terakhir ini lebih mendasar dan dapat mencapai lebih jauh.

Terhadap pertanyaan "apakah maksimalisasi kekayaan pemegang saham itu bersifat imoral?", Dobson (1999) memberikan jawaban dengan memasukan unsur moralitas ke dalam setiap pengambilan keputusan dalam berusaha. Tujuan memaksimalkan keuntungan dalam rangka mempertahankan kesehatan keadaan keuangan perusahaan perlu dijalankan dengan mempertimbangkan kepentingan stakeholders lainnya. Perhatian yang lebih luas ini dapat mendukung kehidupan usaha atau perusahaan itu sendiri. Dalam kesimpulannya, Dobson mengatakan bahwa sebagai seorang profesional, orang tidak dapat menghapus akal sehat moral, dan di situ berperan karakter dan pertimbangannya. Dalam melakukan pertimbangan, kebajikan diperlukan dan ini meliputi sikap kehati-hatian, kearifan dan rasa belas kasihan pada orang lain. Dengan demikian, dapat dikatakan bahwa keuntungan hanyalah alat untuk mencapai tujuan, tetapi tujuan yang sesungguhnya adalah lebih luas dari sekedar keuntungan. Menurut pandangan Immanuel Kant (Bowie, 1998), tujuan itu mencakup pemberian pekerjaan yang berarti bagi masyarakat, memproduksi barang atau jasa yang berkualitas, dan akhirnya menciptakan kesejahteraan bagi orang yang lebih banyak. Dengan mencapai tujuan yang lebih luas ini, kepentingan stakeholders lainnya dapat dipenuhi dan juga dapat melanggengkan usaha itu sendiri.

Penekanan pada masimalisasi keuntungan dalam arti materiel semata dapat berarti adanya pengurangan terhadap kepentingan para stakeholders. Secara menyeluruh, keuntungan merupakan faktor penentu dalam menggerakkan ekonomi, karena keuntungan mendorong orang untuk berproduksi dengan menghadapi risiko. Untuk berproduksi, diperlukan tenaga kerja, sehingga menciptakan lapangan kerja. Keuntungan merupakan kompensasi dari hasil kerja yang baik dan penanganan risiko yang dihadapi. Oleh karena itu, dalam berusaha atau berproduksi, keuntungan perlu dibagi, demikian pula risiko (Vogel dan Hayes III, 1998: 235). Pengusaha berbagi keuntungan dengan pemilik modal sesuai dengan hasil yang secara riel diperoleh bersama. Keuntungan yang dibagi adalah bersifat riel, tetapi tidak tetap atau bervariabel karena tergantung dari hasil usaha yang dapat berbeda dari waktu ke waktu, dan bukan keuntungan akunting atau keuntungan gelembung (Lewis, 2009: 297).

Tanpa adanya bunga yang bersifat tetap, risiko yang dapat dihadapi dalam berusaha atau berproduksi akan lebih kecil. Dengan beban biaya lebih rendah, 
keuntungan akan lebih besar, sehingga perekonomian akan mendorong lebih banyak kegiatan produksi. Karena keuntungan dari usaha atau berdagang diijinkan, maka ekonomi Islam lebih menekankan pada sektor riel. Faktorfaktor riel yang terkait, seperti perbaikan dalam teknologi dan sumber daya manusia, akan mendorong peningkatan secara bertahap dalam produksi atau kegiatan ekonomi (El-Diwany, 2003: 217).

Adalah kombinasi dari usaha atau kerja, modal dan risiko yang menghasilkan return terhadap modal atau uang. Oleh karena itu, keuntungan harus dibagi, demikian pula risiko. Pengusaha berbagi keuntungan dengan pemilik modal sesuai dengan hasil yang diharapkan bersama, tidak ditentukan di depan seperti bunga, tetapi ditetapkan sesuai dengan perkembangan hasil usaha dalam waktu yang berjalan.

\section{Non Gharar}

Sunah Nabi menunjukkan contoh-contoh yang melarang transaksi bersifat tidak pasti, atau excessive speculative risk (Saeed, 2004: 114) atau gharar. "It refers to a number of transactions characterized by risk or uncertainty at their inception", misalnya jangan membeli ikan yang masih berada di laut, karena itu adalah gharar (Hooker, 2004: 87-88).

Gharar berarti sesuatu yang tidak jelas, atau dapat bersifat tipu daya atau desepsi atau berupa hazard, atau sesuatu yang tersembunyi, atau informasi yang tidak terungkap atau tidak diungkapkan, dengan membawa konsekuensi yang tidak pasti, atau menimbulkan ketidakpastian yang berlebihan (Elgari, 2003: 17). Dalam praktik, Gharar dapat merupakan sesuatu yang bersifat ambigu, atau ketidak-jelasan yang berkaitan dengan pihak-pihak dalam suatu transaksi seperti penjual dan pembeli, objek atau harga objek dari transaksi itu (Rosly, 2005: 75); atau merupakan praktik-praktik desepsi atau misrepresentasi mengenai kualitas, harga, jenis dan spesifikasi barang (Rahman, 2010: 43). Keseluruhan faktor ini akan membuat salah satu pihak berada pada posisi yang tidak seimbang karena dihadapkan pada unsur-unsur transaksi yang tidak jelas. Sole (2007) menyebutkannya gharar sebagai ketidakjelasan dalam berkontrak.

Untuk menghindari unsur gharar dalam berkontrak, diperlukan keterbukaan informasi yang lengkap dan hal ini akan mendorong timbulnya transparansi yang lebih baik, sehingga asymmetric information dapat diperkecil (Gait dan Worthington, 2007). Gharar juga diartikan sebagai sesuatu yang memiliki konsekuensi yang belum diketahui atau majhul al aqiba, atau sesuatu yang tidak ada atau habal al-habala, atau sesuatu yang tidak dapat diberikan atau diserahkan seperti kuda yang telah lepas, atau sesuatu yang tidak diketahui 
sama sekali atau majhul mutlaq, atau sesuatu yang dapat disebut tetapi tetap tidak diketahui jenis atau kualitasnya (Ebrahim dan Joo, 2001), seperti ikan di laut.

Dalam penerapannya, gharar juga dapat berarti melaksanakan suatu usaha tanpa memiliki pengetahuan yang memadai (Siddiqi, 2006), atau usaha yang mengandung risiko yang berlebihan, dan tidak perlu atau bersifat spekulatif. Risiko yang dimaksud di sini bukan risiko bisnis normal yang muncul dari keadaan pasar atau systematic risk atau atau dari keadaan keuangan atau disebut sebagai unsystemic risk. Risiko yang pertama berkaitan dengan harga, peraturan, tenaga kerja, sifat suatu industri, keadaan penawaran dan permintaan dan lain sebagainya; sedangkan yang kedua berkaitan masalah likuiditas, kredit, mata uang, ketersediaan kredit dan sebagainya. Pada dasarnya, kedua macam risiko ini memang selalu ada ketika berhadapan dalam suatu bisnis atau transaksi. Menurut Vogel, risiko atau ketidak pastian dalam gharar adalah risiko yang bersifat spekulatif murni, dengan manfaat masa depan yang tidak diketahui, hasil yang tidak jelas, dan tidak teliti atau tidak cermat (Warde, 2000: 60). Gharar yang berlebihan berarti risiko tidak dapat dikontrol, sehingga mengarah pada spekulasi dan judi (Abullah dan Chee, 2010: 54) atau tindakan yang bersifat untung-untungan. Jadi, gharar bukanlah risiko yang dimaksud dalam "al-ghurmu bil ghunmi", karena keuntungan yang diperoleh dari transaksi yang mengandung unsur yang bersifat gharar adalah tidak halal.

Sesungguhnya, konsep gharar ini berusaha untuk menekan asymmetric information sebanyak mungkin, yang merupakan masalah utama dalam intermediasi keuangan. Sebagai salah satu dari karakteristik dari pembiayaan atau finance (Caprio Jr, 1996: 3) ${ }^{3}$, asymmetric information ini merupakan keadaan karena pasar keuangan tidak memiliki informasi yang sempurna; artinya setiap pihak yang terkait dalam suatu transaksi keuangan tidak memiliki informasi yang sama atau seimbang. Di lain pihak, menurut Caprio Jr (1996), sebagai information intensive nature of banking, bank membutuhkan banyak informasi terutama mengenai calon debitor, atau debitornya selama pinjaman belum dilunasi. Bank sebagai calon kreditor, dan salah satu pihak dalam perjanjian kredit yang dibuat, tidak memiliki informasi yang sama seperti pihak lainnya, yaitu calon debitor atau debitor peminjam. Bank, dan calon debitor, memiliki persepsi dan sikap terhadap risiko yang berbeda. Atas keperluannya masing-masing, bank harus lebih berhati-hati terhadap risiko, sedangkan calon

${ }^{3}$ Caprio Jr (1996) menyebutkan 3 karakteristik dari keuangan atau finance, yaitu: information asymmetric, intertemporal trade, dan some demandable debts. 
debitor bersikap lebih berani dalam mengambil risiko. Baik ex ante maupun ex post, calon debitor memiliki informasi yang jauh lebih baik mengenai dirinya, perkembangan usaha, dan masalah yang dihadapinya. Sebelum pinjaman disetujui, calon debitor cenderung memberikan informasi yang lebih baik, yang dapat menambah kemungkinan permohonannya disetujui bank. Kecendrungan ini harus diimbangi oleh bank dengan mendeteksi perbedaan dengan kenyataan yang sebenarnya, dan memastikan fakta yang sesungguhnya.

Islam menghendaki umatnya agar bertabayyun, temasuk ketika akan melakukan transaksi komersial. Pihak bank, misalnya, harus mempelajari secara saksama transaksi dan kualitas pihak dengan mana transaksi itu akan dilakukan. Bahan baku utamanya adalah informasi, yang menyangkut sifat, objek, subjek dari transaksi, di samping keuntungan yang dapat diperoleh dan risiko yang dihadapi. Konsep tabayyun mengendaki untuk mempelajari kebenaran setiap informasi yang diterima. Baik dalam sektor keuangan konvensional atau syariah, masalah asymmetric information selalu ada, dan harus diatasi oleh pihak bank. Dalam pembiayaan, informasi yang diperlukan tidak saja bersifat kuantitatif, tetapi juga bersifat kualitatif, karena penekanan pada informasi kuantitatif semata akan menyesatkan.

\section{Non Maysir}

Alqur' an mengutuk judi atau maysir, atau "games of change, that invokes enmity and distracts the faithful from worship" (Vogel, (et.al), 1998: 64). Kata maysir dalam bahasa Arab secara harfiah adalah memperoleh sesuatu atau keuntungan dengan mudah tanpa kerja, atau dapat disebut judi (Amrin, 2006: 59). Unsur yang bersifat spekulatif membawa kepada situasi untung-untungan atau maysir atau judi. Judi dilarang oleh Alqur'an (QS. 5: 90, 91), karena pada intinya judi merupakan usaha untuk memperoleh harta tanpa kerja, dan memiliki sifat yang menimbulkan mudharat yang lebih besar dari manfaat yang dapat diperoleh, baik bagi individu maupun masyarakat. Judi, pada intinya menjauhkan orang pada unsur kerja dan penciptaan lapangan kerja; segala bentuk usaha yang mengandung unsur spekulasi juga dilarang. Dalam kaitan ini, bank dilarang untuk melakukan jual beli risiko keuangan atau financial risk, karena ini menyerupai judi atau maysir (Cihak dan Hesse, 2008). Kegiatan yang bersifat spekulatif menganggu stabilitas, yang cenderung menimbulkan distorsi terhadap kedamaian dan kemaslahatan masyarakat, sehingga bertentangan dengan maqasid al syariah.

\section{Penekanan Pembiayaan Bukan Pada Utang (Uang).}


Karena Islam melarang adanya riba, dan Nabi Saw menganjurkan untuk tidak mengambil utang (Abdulah Saeed, 2004b: 200). Ekonomi Islam lebih menekankan pada modal bersama atau equity based, dan konsep leverage tidak dapat dipakai. Prinsip leverage atau gearing dalam banyak kasus di dunia telah mendorong timbulnya kegiatan ekonomi yang spekulatif; dan jika digunakan secara berlebihan (Chapra, 2000: 299), telah terbukti menimbulkan krisis keuangan dari waktu ke waktu. Di lain pihak, sistem keuangan Islam yang terstruktur dengan baik tidak mencakup kegiatan spekulatif (El-Diwany, 2003: 201).

Dalam perbankan syariah, utang yang ditimbulkan dari pinjam-meminjam murni dibedakan dengan utang yang ditimbulkan karena perniagaan, usaha, atau investasi; yang terakhir ini disebut sebagai "pembiayaan". Bagian berikut membahas secara umum mengenai perbedaan keduanya, dan secara khusus mengenai pembiayaan. Setiap, barang yang dapat dijual, dapat menjadi pinjaman atau di pinjamkan, contohnya emas dan perak, serta barang dagangan; di samping uang. Utang atau pinjaman dalam Islam dibagi menjadi 2 macam berdasarkan kegunaan atau sumber keperluannya.

Pertama: Utang, loan, atau qard. Utang di sini merupakan pinjam meminjam sesuatu yang berharga dari yang berkelebihan kepada yang membutuhkan. Ketika uang telah dikenal, maka utang di sini berarti 'money lending and borrowing' atau 'loan' dengan dasar ada sejumlah uang yang dipinjamkan. Menurut Muldrew (2001: 134), utang semacam ini baru muncul di pertengahan Abad XVI. Umumnya, utang ini muncul atas keperluan konsumsi atau untuk keperluan sehari-hari yang mendesak, sehingga merupakan suatu kegiatan sosial atau tabarru. Dalam Nicomachean Ethics, Aristoteles mengatakan bahwa sudah merupakan tugas seseorang untuk menebus teman atau keluarga terdekat; karena pada waktu itu utang yang dikenal di Anthena umumnya adalah untuk konsumsi atau pinjaman non produktif, termasuk melepaskan seseorang dari perbudakan (Millet, 2002: 59). Utang yang bersifat non produktif ini biasanya terjadi dalam kaitan ketidakberuntungan, atau kejadian yang muncul di luar dugaan seperti kematian atau membayar uang tebusan, serta dapat terjadi pada semua orang dari semua golongan sosial. Di samping itu, terdapat utang non produktif tetapi yang diperlukan dalam kaitan keperluan prestise, seperti untuk pembelian persenjataan atau barang-barang mewah; tetapi utang macam ini hanya berkaitan dengan segelintir orang, yang berada pada tingkat sosial yang lebih tinggi. 
Walaupun bersifat sosial, utang atau pinjaman ini harus dibayar kembali, karena merupakan pemindahan hak seseorang kepada orang yang meminjamnya untuk sementara. Karena bersifat sosial, pembayaran kembali hak tersebut harus dilakukan tanpa tambahan, keuntungan, atau riba (Iqbal dan Mirakhor, 2007: 63; Nawawi, 2009: 147). Walaupun utang seperti ini, dengan akad yang bersifat sosial, Nabi Muhammad Saw sangat menganjurkan agar umatnya tidak mengambil atau menggunakan utang, kecuali jika terpaksa (Saeed, 2004: 200).

Kedua: Pembiayaan. Macam utang yang kedua bersumber dari transaksi komersial, atau berkaitan dengan perdagangan, atau investasi dengan tujuan produktif. Menurut Muldrew (2001: 95), umumnya, sebelum Abad XVIII, istilah kredit merupakan utang yang timbul dan berkaitan dengan transaksi jual beli. Di sini, utang berarti sebagai 'debt', atau kewajiban membayar tangguh terhadap suatu transaksi komersial atau jual beli yang telah terjadi. Pembayarannya diperjanjikan untuk dilakukan dalam waktu yang ditentukan. Oleh karena itu, dalam terminologi bank syariah, 'pinjaman' atau penggunaan uang pihak lain yang terjadi dalam kaitan dengan suatu transaksi komersial disebut sebagai "pembiayaan".

\section{Transaksi Keuangan Hanya dengan Akad-Akad Yang Disediakan}

Secara filosofis, jika seorang calon nasabah datang kepada bankir konvensional, pertama kali akan menanyakan “ berapa besar pinjamannya?", karena prima kausa dari perjanjian kredit adalah uang. Tetapi, jika datang kepada bankir syariah, maka pertanyaan adalah "apa transaksinya" atau "untuk pembiayaan apa"? Hal ini disebabkan karena perjanjian atau akad bank syariah bertitik tolak pada underlying transaction, yang merupakan prima kausa akad, dan bukan pada peminjanan uang. Underlying ini akan terlihat dari akad-akad yang disediakan.

\section{a). Akad-Akad dan Prima Kausa Akad: Barang, Jasa atau Usaha}

Akad-akad pembiayaan utama dikelompokan menjadi tiga, yaitu: Kelompok Jual Beli, Sewa, dan Kerja Sama atau Bagi Hasil, sebagai berikut. Kelompok akad: Jual Beli. Jenis Transaksi: Murabaha dan Salam dan Istishna. Kelompok Akad: Sewa. Jenis Transaksi. Ijara: Ijarah Muntahiya bi Tamblik (IMBT), atau nama lain Ijara Wa Iqtina ${ }^{4}$.

${ }^{4}$ Merupakan bentuk lain dari Ijarah Muntahiya bi Tamblik (IMBT), yang merupakan rangkaian 2 akad, akad jual beli atau al bai dengan akad ijarah, dan menunjukkan adanya 2 transaksi yaitu sewa menyewa dengan jual beli atau hibah di akhir masa sewa (Anshori, 2002: 56). 
Kelompok Akad: Kerja sama atau bagi hasil atau PLS ${ }^{5}$. Jenis Transaksi: Mudharabah, Musharakah, Musharakah Mutanaqisah

\section{b). Pembiayaan Melekat Pada Sektor Ekonomi Riel.}

Seluruh akad di atas seperti muarabaha, salam, istisna, dan ijara, menjadikan suatu jenis barang yang telah ada atau yang akan diproduksi sebagai prima kausa akad, dengan dasar transaksi jual beli atau sewa. Akad Mudharabah dan musharakah terjadi karena adanya usaha tertentu di dalam sektor riel sebagai titik tolak terjadinya akad, dengan dasar transaksi pembiayaan bersama. Pada dasarnya, akad-akad ini bukan seperti perjanjian kredit pada bank konvensional, dan di dalamnya, uang merupakan inti dari perjanjian. Jual beli, sewa, atau pembiayaan bersama merupakan underlying transaction bagi pembiayaan Islam.

Oleh karena itu, jika ditinjau dari kedua hal tersebut, yaitu obyek dari suatu akad dan bagaimana dana digunakan untuk masing-masing akad, dapat dikatakan bahwa akad- akad bank syariah melekat erat pada sektor ekonomi riel. Kedekatan ini membuat sistem keuangan Islam lebih stabil, karena sektor keuangan dan sektor riel menyatu, dan tidak menimbulkan dikotomi dari keduanya.

\section{c). Uang Mengikuti Alur Barang dan Jasa.}

Dalam Islam, utang atau piutang tidak dapat diperdagangkan seperti halnya pada perbankan konvensional ${ }^{6}$, baik secara langsung melalui sekuritisasi. Salah satu alasannya adalah, dalam perbankan syariah, uang mengikuti alur barang atau jasa. Jika ditinjau dari transaksi yang terkait dengan penjualan utang atau piutang itu, maka terdapat dua macam transaksi yang perlu diuraikan. Pada transaksi pertama, umumnya, merupakan transaksi jual beli suatu barang dengan pembayaran tangguh atau dengan kredit, sehingga menciptakan utang dan piutang bagi masing-masing pihak dalam transaksi. Kemudian, pada transaksi kedua, yaitu ketika piutang itu dijual, maka di sini tidak ada lagi alur barang yang mengimbanginya.

\footnotetext{
${ }^{5}$ Banyak literatur menyebutkan akad ini sebagai "profit and loss sharing atau PLS agreement".

${ }^{6}$ Menurut Usmani (2002: 221), jual- beli piutang diijinkan di Malaysia berdasarkan ketentuan dari mazab Shafai; tetapi, menurut Usmani, mereka tidak menyadari bahwa penjualan tersebut harus dilakukan berdasarkan nilai par. Rosly (2005: 437) berpendapat bahwa penjualan utang dari kreditor ke pihak ketiga atau bay'al-dayn lil ghairil mad'ine dilarang, karena penjualan seperti ini menyangkut adanya premiun atau diskon; tetapi, bay'al-dayn tertentu, atau berasal dari transaksi murabaha dengan pembayaran tunda, emas kawin yang tertunda, pembayaran sewa yang harus dibayar setiap akhir bulan, dengan syarat dijual pada harga par, dan utang itu telah dipastikan adanya-diperbolehkan.
} 
Dengan menggunakan pendekatan lain, penjualan utang ini dapat dijelaskan sebagai suatu penukaran uang dengan jumlah uang yang berbeda di masa depan, sehingga tidak membawa manfaat yang berkaitan langsung dengan produktivitas (Siddiqi, 2006). Dengan demikian, transaksi kedua tersebut bukan lagi transaksi yang berkaitan dengan barang, atau melekat pada sektor riel, tetapi merupakan transaksi sektor keuangan yang bergerak menjauhi sektor riel. Menurut para ahli, hal inilah yang menyebabkan dikotomi antara sektor riel dengan sektor keuangan, dan sekaligus menimbulkan ketidakstabilan paling tidak pada sektor keuangan itu sendiri (Al-Jarhi, 2008: 10).

\section{d). Penggunaan Dana Lebih Terkontrol.}

Pada umumnya, penggunaan uang atau fund disbursement lebih jelas dapat dilihat atau dikontrol, karena mengikuti alur barang atau usaha. Kemungkinan penyimpangan dalam penggunaan dana, atau kemungkinan wanprestasi akibat dari penyimpangan penggunaan dana dari yang telah disepakati, dapat diperkecil. Tambahan pula, praktik penggunaan dana untuk tujuan spekulasi tidak dimungkinkan, karena pembiayaan yang mengandung unsur gharar atau maysir memang dilarang dalam ekonomi Islam atau perbankan Syariah.

Pada akad murabahah dan ijarah, dana digunakan langsung untuk membeli barang yang diperlukan nasabah. Pada akad salam atau istishna, dana diberikan pada nasabah untuk menanam barang pertanian atau memproduksi barang tertentu dalam sektor riel. Pengawasan penggunanan dana lebih terkontrol pada istishna, karena pembayaran dapat tidak dilakukan sekaligus tetapi bertahap berdasarkan progres. Pada akad salam, di lain pihak, pembayaran untuk pembelian barang harus dilakukan sekaligus di muka, dalam rangka meringankan beban petani untuk menanam komoditas pertanian yang diperlukan, sekaligus untuk keperluan hidupnya selama musim tanam hingga panen. Ditinjau dari sifat nasabah seperti ini, kemungkinan terjadinya penyimpangan penggunaan dana secara intuitif dirasakan tidak besar. Umumnya, para petani hanya memiliki pengetahuan dan keahlian sebagai petani, dan mereka sebagai petani sangat berkepentingan dengan usaha tanam dan memperoleh panen berlanjut dari waktu ke waktu.

Namun, hal ini tidak dapat dilakukan pada akad mudharabah berdasarkan beberapa dasar pemikiran tertentu. Pertama, sebagian besar para ahli mengatakan bahwa modal yang dimaksudkan dalam akad mudharabah haruslah berbentuk modal uang, karena jika tidak, nilai modal awal hanya dapat diperkirakan, atau dapat bersifat gharar; dan hal ini akan menyulitkan 
pembagian keuntungan, sehingga dapat menimbulkan perselisihan di kemudian hari (Al- Zuhayli's, 2003: 493-494). Kedua, uang dapat digunakan untuk berbagai tujuan dalam rangka membentuk dan menjalankan usaha sesuai dengan keahlian dan kemampuan mudharib; sedangkan jika berbentuk barang, maka akan membatasi ruang gerak atau fleksibilitas mudharib dalam berusaha (Al-Zuhayli's, 2003: 495).

Pada akad musharakah, setiap mitra dapat melakukan pengontrolan pengelolaan dana secara langsung. Seluruh mitra menjadi pengelola dari suatu usaha, dan tidak ada dari mereka yang hanya menjadi penonton seperti halnya pihak kreditor dalam perjanjian kredit bank konvensional. Dengan ikutnya pemodal atau bank sebagai mitra pengelolaan usaha, kemungkinan terjadinya moral hazard dan adverse selection dalam pemilihan usaha dan pengelolaan dana dapat dihindarkan (Al-Jarhi, 2008: 11). Setiap partner cenderung memperoleh informasi dengan kualitas yang cenderung sama. Ini artinya asymmetric information juga dapat diperkecil.

\section{e). Menggunakan Dana Quasi Equity Untuk Investasi: Bukan Utang.}

Secara umum, Nabi Saw menganjurkan agar manusia tidak menggunakan utang, jika tidak terpaksa. Beliau pernah berdoa: "Ya, Allah, jauhkanlah saya dari kegundahan dan kesedihan, kelemahan dan kemalasan, kebodohan dan kebathilan, keberatan utang, serta tekanan dan paksaan orang" (HR Muttafaqun Alaihi dari Anas; Sihab, Quraish, 2013: 237). Dari doa ini terlihat bahwa keberatan utang disetarakan dengan kesedihan dan kelemahan, yang dapat menimbulkan tekanan atau paksaan agar utang dibayar. Sabda Nabi Saw yang lain menyebutkan bahwa "Jika orang berutang, ia tidak segan-segan berbohong, dan mengingkari janji" (HR muslim dan Abdullah bin Umar). Jika orang memiliki utang yang besar, ada kecendrungan jika berbicara dia akan berdusta, dan jika berjanji dia tidak menepati ${ }^{7}$ (Taufik, 2004: 145). Karena memiliki utang, orang cenderung meninggalkan sifat-sifat yang baik pada dirinya.

Ditinjau dari substansi akad-akad, dapat dilihat bahwa pembiayaan syariah tidak menggunakan utang uang secara an sich. Pada akad murabaha, salam, ishtisna, dan ijara, kewajiban membayar atau 'debt' adalah berkaitan dengan jual-beli dengan pembayaran tangguh, pemesanan, dan penyewaan barang. Dalam hal ini, pembiayaan Islam disebut sebagai asset based. Dana dalam akad

${ }^{7}$ Apa yang disampaikan Nabi SAW ini, beberapa ratus tahun kemudian juga diutarakan melalui ungkapan "if you loan a man too much money, you turn a good man into a bad man" (Warde, 2000: 163) 
mudharabah dan musyarakah merupakan dana investasi, yang bersifat sebagai quasi equity, atau menyerupai dana ekuitas, bukan bersifat sebagai utang, sehingga juga disebut sebagai equity based. Oleh karena itu, pembiayaan Islam tidak mengenal konsep leverage, yang diartikan sebagai penggunaan utang uang sebagai pengungkit perolehan pendapatan dan keuntungan.

Di belakang penggunaan leverage ini, terdapat risiko yang besar dan serius, jika terjadi sesuatu yang salah (Moriss, 2008: 50). Pengambilan utang yang berlebihan atau over leverage merupakan salah satu sebab, yang menimbulkan ketidakstabilan dan menambah besarnya risiko sistemik (Askari, Iqbal, Krichene, dan Mirakhor, 2010: 23, 154). Rasio leverage yang tinggi dapat menunjukkan tingkat agresivitas seseorang terhadap risiko, dan bahkan dapat pula dikaitkan dengan unsur moralitas ${ }^{8}$. Pengambilan pinjaman atau utang menambah risiko usaha bagi debitor, dan risiko kredit bagi kreditor ${ }^{9}$. Menurut Chorafas (2000), orang yang menggunakan pinjaman atau utang yang berlebihan atau over leverage ${ }^{10}$ menunjukan bahwa orang tersebut melakukan praktik etika yang meragukan. Konsep over leverage, penggunaan utang uang yang berlebihan, bertentangan dengan karakteristik pembiayaan Islam.

Dalam perhitungan Debt Equity Ratio atau DER, dari neraca nasabah atau debitor, kewajiban membayar yang berkaitan dengan murabahah adalah setara dengan utang dagang atau account payables, yang merupakan pembiayaan yang diperoleh dari kegiatan dalam perdagangan; bukan merupakan 'pinjaman uang' dari bank, walaupun pembiayaannya berasal dari bank. Untuk akad salam atau ishtisna, pembayaran di muka dicatat di bagian aktiva neraca, yang merupakan aset dari nasabah. Karena bersifat sebagai quasi equity, dana yang diperoleh dari akad mudharabah dan musharakah tidak dapat dikategorikan sebagai liabilitas atau kewajiban. Jumlah ini lebih condong dimasukan sebagai bagian mendekati ekuitas. Dalam keadaan yang paling buruk, kewajiban ini dibayar setelah

${ }^{8}$ Dalam kaitan dengan moralitas, Chorafas berpendapat bahwa negara yang memiliki utang lebih dari 100\% dari GDP tahunannya berarti memberikan beban bagi generasi berikutnya di negara tersebut; beban mana dapat berakibat buruk bagi generasi tersebut (Chorafas, 2000: $66)$.

${ }^{9}$ Semakin tinggi tingkat leverage atau semakin rendah tingkat modal dari suatu entitas, semakin sedikit adverse shock yang diperlukan bagi entitas itu untuk mengalami economic insolvency; dan ini berlaku baik bagi bank maupun non-bank (Kaufman, 2001).

10 Dari sisi lain, menurut Michael Jensen (1989), keadaan overgearing tidak akan berakibat pada kebangkrutan, karena kreditur akan berada dalam posisi yang lebih baik jika berusaha untuk melakukan renegosiasi. Namun, pendapat ini dibantah oleh Nakamura (1991: 19), dengan alasan bahwa pada perusahaan dengan leverage yang berlebihan, umumnya mereka memiliki margin yang sangat tipis, dan tidak memiliki kolateral tambahan, sebagai dasar untuk bernegosiasi. 
seluruh kewajiban lain dilunasi, atau bersifat 'residual'. Oleh karena itu, cara perhitungan DER harus disesuaikan, demikian pula cara membacanya.

\section{Bersifat Berbagi Risiko/Risk Sharing, Bukan Risk Transfer}

Dalam menjaga keharmonisan, tolong menolong dalam menghadapi risiko atau berbagi risiko merupakan tema yang penting dalam kehidupan sehari-hari. Hak dan tanggung jawab dari setiap pihak dalam akad telah ditentukan sejak semula. Namun, kerja sama sangat diperlukan untuk mencapai kepentingan bersama, dan menyelesaikan berbagai permasalahan. Mencapai keberhasilan bersama merupakan kewajiban setiap muslim, karena bersifat fardhu kifayah (Amrin, 2011: 74). Nabi Saw bersabda, "Siapa yang memenuhi hajat saudaranya, maka Allah akan memenuhi hajatnya" (Hr. Bukhari, Muslim dan Abu Daud).

Konsep berbagi risiko dapat dilihat dalam akad PLS, atas dasar kepentingan bersama dalam mencapai keuntungan. Pada akad mudharabah, risiko bisnis ditanggung oleh pemilik modal atau shahibul mal, dengan konsekuensi modalnya dapat terkikis karena kerugian yang mungkin timbul. Dalam keadaan rugi, mudharib kehilangan kesempatan untuk berbagi hasil, karena memang sejak awal mudharib tidak memiliki modal, kecuali waktu, tenaga dan keahliannya. Ini merupakan kerugian baginya, karena telah memberikan kontribusi berupa waktu, tenaga, dan keahlian.

Pada akad musharakah, karena masing-masing mitra memiliki dan berkontribusi modal usaha, maka setiap mitra menanggung kerugian, atas dasar berbagi keuntungan secara bersama. Seperti yang tersirat dalam Alqur'an (QS. 5: 2), Islam mendorong dan mempromosikan konsep kerja sama berdasarkan kepercayaan atau amanah dengan membagi risiko yang dihadapi, atau risk sharing bagi pihak yang berpartisipasi dalam suatu bentuk usaha. Dalam pembiayaan konvensional, risiko usaha dipindahkan ke pihak lain, atau merupakan risk transfer. Dalam kaitan dengan riba, debitor menanggung risiko usaha dengan dibebankan bunga yang ditetapkan di awal perjanjian. Terlepas bagaimana perjalanan usaha yang dibiayai, kreditor menerima bunga yang pembayarannya bersifat pasti.

Di samping itu, jual beli utang-piutang, seperti menjual surat utang atau sekuritas, atau menjual piutang atau factoring, merupakan kegiatan yang umum dan wajar dalam pembiayaan konvensional. Al-Haddad dan Timol (2008) berpendapat, bahwa secara teoretis, perdagangan utang itu merupakan tindakan penyebaran risiko di antara sejumlah bank yang berbeda, sehingga mengurangi risiko bagi setiap bank yang terkait. Berdasarkan definisi yang diberikan oleh 
Nagaoka (2009), penyebaran risiko yang dimaksud oleh Al-Haddad dan Timol itu lebih cenderung berarti risk scattering, bukan risk sharing. Seperti yang dikatakan oleh Otaki (2008: 109), Nagaoka berpendapat bahwa suatu transaksi sekuritas bersifat sebagai penyebaran risiko atau risk scattering, apabila pemindahan risiko atau risk transfer, dari bank kepada para investor atau para individu, lebih banyak berpotensi untuk menimbulkan akibat yang merugikan pada tingkat ekonomi makro, bagi seluruh pihak yang terkait.

Akibat negatif itu timbul karena pemindahan risiko tersebut, yaitu berasal dari pihak yang memiliki cukup pengetahuan dalam mengelola risiko kepada pihak yang tidak memiliki pengetahuan tentang risiko yang dihadapi; sehingga, transaksi keuangan itu menimbulkan masalah information asymmetric yang lebih besar. Pihak yang memiliki piutang, atau yang memberikan utang pertama kali atau kreditor awal, lebih mengetahui sifat dan kualitas debitornya. Pihak yang membeli piutang itu tidak memiliki pengetahuan sebaik kreditor pertama mengenai sifat dan kualitas debitor itu. Di sini Nagaoka menekankan, bahwa penjualan Collateralized Debt Obligation atau CDO dari subprime mortgage, misalnya, adalah merupakan risk scattering, bukan risk sharing. Namun, masalah information asymmetric tersebut dijembatani oleh rating yang dikeluarkan oleh para rating agencies. Para investor atau para individu pembeli $\mathrm{CDO}$, yang merupakan paket atau pool yang terdiri dari prime dan subprime mortgage (al-Haddad dan Timol, 2008), mengambil keputusan untuk membeli sekuritas itu semata-mata berdasarkan rating tersebut. Ternyata, kemudian diketahui bahwa rating tersebut mengandung masalah karena adanya unsur rekayasa.

\section{Wajib Bersifat Amanah dan Menepati Janji}

Islam berusaha untuk membangun masyarakat berdasarkan kejujuran dan keadilan (QS. 2: 239), yang merupakan dasar pokok dalam bermuamalah. Alqur'an memerintahkan manusia untuk bersifat amanah, "Sesungguhnya Allah menyuruh kamu menyampaikan amanat kepada yang berhak menerimanya, dan (menyuruh kamu) apabila menetapkan hukum di antara manusia supaya kamu menetapkan dengan adil (QS. 4: 58). Amanat yang dimaksud adalah taklif, tanggung jawab dan hukum. Artinya, kehidupan manusia harus dibangun atas dasar tugas dan tanggung jawabnya. Hukum dapat diberlakukan hanya kepada manusia dan dalam kehidupannya (Muthahhari, 2011: 17).

Amanat adalah mengembalikan setiap hak kepada pemiliknya, tidak mengambil hak orang lain, tidak mengambil sesuatu melebihi haknya, dan tidak mengurangi hak orang lain, baik berupa harga atau upah (QS. 4: 29). Dalam 
berdagang dikenal istilah 'menjual dengan amanat' seperti dalam murabahah. Maksudnya, penjual menjelaskan ciri-ciri, kualitas, dan harga barang dagangan kepada pembeli yang berhak menerimanya. Dalam berserikat dengan akad mudharabah dan musharakah lebih penting lagi. Pihak yang dipercaya dan memegang janji demi kemaslahatan bersama. Jika salah satu pihak menjalankannya hanya demi kemaslahatan pihaknya saja, maka ia telah berkianat (Qardhawi, 1997: 177).

Menurut Orgianus (2012: 92), amanah menyangkut segala hak, yaitu hak milik Allah atau hak perseorangan, yang harus dipertanggungjawabkan dan diemban oleh seseorang. Hak perseroangan dapat berupa pekerjaan, perkataan ataupun kepercayaan orang lain kepada si pengemban amanah tersebut. Untuk dapat memenuhi amanah yang diemban, pemegang amanah harus memiliki kemampuan, atau keahlian, untuk menjalankan atau memenuhi amanah itu. Pemegang amanah haruslah yang benar-benar dapat dipercaya, dengan keimanan yang kuat, dan bersedia meninggalkan keraguan, agar tetap memegang kesucian agamanya (Orgianus, 2012: 93-95).

Amanah juga berarti kepercayaan atau trust. Beberapa ahli atau para filsuf memberikan definisi atau pengertian dari kepercayaan secara umum, dan terlepas dari masalah janji. Dalam arti yang sederhana, trust identik dengan kepercayaan atau confidence. Menurut Shaw (1997: 21), trust dalam bahasa Jerman, trost, berarti 'nyaman', dan merupakan penilaian awal terhadap kemampuan karakter seseorang atau suatu institusi atau organisasi, tidak selalu dibentuk dari pengalaman; tetapi sebagian dibentuk atas kepercayaan atau faith. Shaw menyimpulkan, bahwa trust adalah bahwa seseorang atau suatu institusi selalu menunjukkan hasil, bertindak dengan integritas, serta menunjukkan perhatian terhadap orang lain.

Menurut Bloomgarden (2007: 13), terdapat empat unsur yang dapat membentuk trust, yaitu memberikan hasil yang nyata, bertindak dalam normanorma etika, mendengarkan apa yang harus disampaikan oleh orang lain, dan bersikap terbuka atau transparan dalam apa yang dilakukan. Menurut Shaw (1997: 21), trust adalah suatu kepercayaan yang diberikan pada seseorang atau suatu institusi yang dapat memenuhi harapan orang atau pihak yang memberikan kepercayaan. Menurut Muldrew (1998, 148), trust merupakan ikatan sosial yang penting, yang berarti suatu reputasi yang baik dan menggambarkan kejujuran dan realibilitas dalam kaitan dengan kewajiban.

Menurut O' Hara (2004: 71), trust dibentuk dan didukung oleh reputasi; dalam hal ini reputasi yang baik, karena reputasi juga dapat bersifat negatif. 
O'Hara lebih lanjut berpendapat, bahwa reputasi adalah mengandung informasi yang dapat menjawab pertanyaan mengenai dasar reaksi dari aksi yang akan dilakukan, ketika berhadapan atau berhubungan dengan seseorang atau institusi. Reputasi merupakan jaminan, substansi dan fondasi dari kepercayaan, dan sekaligus merupakan prediktor terhadap apa yang akan terjadi. Reputasi adalah bahan dasar atas pembentukan trust.

Fukuyama (1995: 26) berpendapat, bahwa trust merupakan suatu harapan yang muncul dalam masyarakat dari tingkah laku yang biasa jujur, dan dapat bekerja sama berdasarkan norma yang biasa dianut oleh sebagian dari masyarakat. Norma yang dimaksud dapat berasal dari nilai agama atau ketuhanan yang dalam, tapi juga dapat berasal dari standar tingkah laku tertentu yang berlaku untuk kelompok tertentu. Bagi Fukuyama (Baum, 2004: 231), trust akan membangun kerjasama yang saling mempercayai dalam koridor etika yang umum, sehingga membentuk modal sosial di dalam masyarakat. Modal sosial ini akan mendorong pertumbuhan ekonomi industrial dan inovasi pada tingkat organisasi yang lebih baik, dan sekaligus membentuk banyak hubungan sosial dan menurunkan biaya dalam bertransaksi.

Menurut Immanuel Kant (1724-1804), trust merupakan ikatan sosial, dan menekankan bahwa manusia adalah makhluk yang sangat bermoral, yang memiliki pandangan yang kuat terhadap ide adanya tugas yang menyangga pengertian mengenai trust (O'Hara, 2004: 48). Bagi Kant, manusia mampu untuk diatur berdasarkan ketentuan-ketentuan moral, dan ketentuan itu harus bersifat universal, yang artinya bahwa ketentuan itu harus berlaku pada setiap orang secara merata, sehingga wajar dan tepat secara moral.

Seperti halnya dalam perjanjian konvensional, apa yang telah diperjanjikan atau disepakati harus ditepati atau dipenuhi (QS. 2: 283). Allah memerintahkan manusia untuk menepati janjinya, karena "Barang siapa yang melanggar janji, niscaya akibat ia melanggar janji itu akan menimpa dirinya sendiri dan barangsiapa menepati janjinya kepada Allah, maka Allah akan memberinya pahala yang besar". (QS. 48: 10). Surat lain menyebutkan, "Hai orang-orang yang beriman penuhilah akad-akad itu........" (QS. 5: 1). Tuhan telah pula menetapkan bahwa "... Sesungguhnya janji itu pasti diminta pertanggung jawabnya" (QS. 17: 34). Berdasarkan Surat Al Baqarah (QS. 2: 177), Qodri Azizi berpendapat bahwa taqwa juga diartikan sebagai tindakan menepati janji, dan disetarakan dengan beriman kepada Allah sebagai suatu kebajikan, seperti melakukan shalat, menunaikan zakat, dan seterusnya (Azizi, 2004: 97). 
Alqur'an menetapkan bahwa orang-orang yang memelihara amanatamanat dan janji-janjinya adalah yang mewarisi surga Firdaus, dan kekal di dalamnya serta dimuliakan (QS. 23: 8-11; QS. 70: 32-35). Salah satu Hadis Nabi Saw menyebutkan bahwa janji adalah utang, al-wa'du daynun (Azizy, 2004: 102), dan memiliki konsekwensi duniawi dan akhirati (QS. 17: 34; QS 65: 8, 9, 10). Nabi Saw menyatakan bahwa utang harus dibayar; dan bahkan harus dilunasi sebelum seseorang meninggal dunia, karena utang memiliki konsekuensi yang sangat berat, jika tidak dibayar (Akram Khan, tidak bertanggal: 162-163). Nabi Saw enggan untuk menyembayangi seseorang ketika meninggal membawa utang yang belum dibayar (Akram Khan, tidak bertanggal: 162-163). Sabda Nabi Saw menyebutkan, bahwa "Bagi para syuhada akan dihapuskan segala dosa mereka kecuali utang- piutang yang belum mereka bayar" (HR muslim dan Abdullah bin Umar). Sifat sakral atas pembayaran utang sebelum seseorang meninggal juga dijumpai pada kasus Socrates. Dia meminta seorang temannya, Crito, untuk membayarkan utang yang dimilikinya dalam bentuk ayam jantan, sebelum meminum racun hemlock atas perintah penguasa sebagai hukuman baginya. Di sisi lain, Alqur'an memerintahkan agar yang berpiutang memberikan kelonggaran, ketika yang berutang belum mampu membayarnya. Nabi Saw bersabda, di lain pihak, "Pengangguhan pembayaran utang bagi yang mampu merupakan penganiayaan" (HR Al Bukhari dan Muslim; Shihab, Quraish, 2013: 237).

Dalam Islam, pemenuhan kewajiban bersifat amanah dan menepati janji harus dilakukan dengan khidmad, penuh dengan kejujuran dan ketulusan (Nawawi, 2009: 51), karena bukan saja merupakan ketentuan hukum positif, tetapi juga merupakan perintah Tuhan (QS 5: 1). Nabi Saw bersabda, "Tiga golongan yang termasuk munafik meskipun ia berpuasa, shalat, dan mengaku muslim yaitu jika berbicara ia berbohong, jika berjanji ia tidak menepati, jika diamanatkan ia berkhianat" (HR Abu Daud 3383 dan Hakim 2/25 dari Abu Hurairah). Kegagalan atau kelalaian dari masing-masing pihak untuk memenuhi kewajiban atau komitmen ini menimbulkan risiko bagi salah satu pihak. Bagi bank, risiko yang timbul dari pihak nasabah yang tidak memenuhi kewajiban, atau komitmennya berdasarkan suatu akad, merupakan bentuk risiko termasuk risiko kredit atau pembiayaan yang harus dikaji dan dihadapi. Jika ketentuan Tuhan dipenuhi (QS. 23: 8-11; QS. 70: 32-35), maka risiko yang dimaksud dapat diperkecil, dan transaksi bisnis atau bermuamalah dapat dilakukan lebih efektif dan efisisen. 


\section{Penutup}

Prinsip dasar dari ekonomi dan pembiayaan Islam adalah untuk menciptakan kemaslahatan atau kesejahteraan masyarakat, dengan berpatokan pada prisip pokok yang terdiri dari Keesaan Tuhan, konsep Kalifah Tuhan di bumi, keadilan dan keseimbangan material dan spiritual atau duniawi dengan akhirati. Prinsip-prinsip ini dapat dipenuhi dengan mengikuti ketentuan dasar pembiayaan, yaitu melalui kegiatan perdagangan dan menjauhi riba, serta kerja sama antar sesama.

Ketentuan ini membawa makna yang dalam dengan implikasi yang jauh terhadap pencapaian kemaslahatan duniawi masyarakat yang bernilai akhirati. Perdagangan merupakan kegiatan hulu dan hilir dari sektor ekonomi riel, dan menciptakan kebajikan yang luas. Pelarangan riba, di lain pihak, menunjukkan bahwa kegiatan pinjam-meminjam (uang) tidak dapat dikomersialkan, sehingga sektor keuangan tidak dapat berjalan sendiri, tanpa dilekatkan pada sektor riel.

Agar dapat menciptakan kemaslahatan masyarakat, pembiayaan Islam hanya dapat dilaksanakan berdasarkan akad-akad yang disediakan, tanpa riba, gharar, dan maysir, bertujuan untuk memperoleh hasil kerja non ribawi dan keuntungan bersama, menggunakan dana ekuitas (bersama) bukan utang, berbagi risiko, dan dilaksanakan dengan penuh amanah serta menepati janji. Pada saat yang sama, uang difungsikan secara hakiki, yaitu sebagai alat untuk bertransaksi dan pengukur terhadap counter value berupa nilai barang, jasa, dan usaha. 


\section{Daftar Bacaan}

Abdullah Al-Qarny, Aidh. 2010. Islam, Rahmatan Iil Alamin. Jakarta: Cakra Lintas Media.

Abdullah, Amrin. 2006. Asuransi Syariah. Jakarta: Elex Media Komputindo. 2011. Meraih Berkah Melalui Asuransi Syariah. Jakarta: Elex Media Komputindo.

Karim, Adiwarman. 2004. Bank Islam, Analisis Fiqih dan Keuangan. Jakarta: PT. RajaGrafindo Persada.

Agil, Syed Omar Syed, dan Aidit Ghazali. 2005. Readings in the Concept and Metodology of Islamic Economics. Kuala Lumpur: CERT Publications.

Akkas, S.M. Ali. 2009. "Issues and Problems of Islamic Banking in Bangladesh", Akkas54@gmail.com, www.cdss.ingeniousbd.org.

Akram Khan. Tanpa Tahun. Economic Teachings of Prophet Muhammad. Karachi: Darul Ishaat.

Algaoud, Latifa M. Mervyn K Lewis. 2001. Perbankan Syariah. Jakarta: Serambi Ilmu Semesta, www.serambi.co.id. info@serambi.co.id.

Al-Haddad, Haitham, Bashir Timol. 2008. The Credit Crunch: An Islamic Perspective. www.islam21c.com, www.1stethical.com.

Al-Harran, Saad. 1995. Leading Issues in Islamic Banking and Finance. Malaysia: Pelanduk Publications (M), Petaling Jaya.

Al-Jarhi. 2008. Islamic Finance: An Efficient \& Equitable Option, The Islamic and Training Institute, The Islamic Development Bank, PO Box 9201, Jeddah, Saudi Arabia, http//: www.wfdd.org.uk/articles-talks/mabid.fdf.

Al-Zuhayli, Wabbah. 2003. "Financial Transactions in Islamic Jurisprudence", Vol.1. Dar al Fikr, Damascus, Syria. http://www.fikr.com. fikr@fikr.com. Anshori, Abdul Ghofur. 2002. "Perkembangan Hukum Perbankan di Indonesia", dalam Kapita Selekta Perbankan Syariah di Indonesia, Abdul Ghofur Anshori (ed). UII Press, Yogyakarta.

Arifin, Zainul. 2005. Dasar-Dasar Manajemen Bank Syariah. Jakarta: Pustaka_alvabet@yahoo.com.

Azizi, A. Qodri. 2004. Membangun Fondasi Ekonomi Umat. Yogyakarta: Pustaka Pelajar.

Baum, Herb, 2004, The Transparent Leadership, Jakarta: Bhuana Ilmu Populer. Bloomgarden, Kathy, 2007, Trust, The Secret Weapon of Effective Business Leaders, New York: St. Martin's Press.

Bowie, Norman E., 1998, A Kantian Theory of Capitalism, Ruffin Series in Business Ethics, ABI/INFORM Global, pg 37. 
, 1998, Business Ethics, A Kantian Perpective, Blackwell Publishers, Minneapolis.

Caprio Jr, Gerald. Daniela Klingebiel, 1996, Bank Insolvency: Bad Luck, Bad Policy, or Bad Banking?, Annual World Bank Conference on Development Economics 1996, C1997, The International Bank for Reconstruction and Development/The World Bank.

Chapra, M. Umer. Habib Ahmed, 2008, Corporate Governance, Lembaga Keuangan Islam, Jakarta: Bumi Aksara.

Chapra, M. Umer, 2000, Islam dan Tantangan Ekonomi, Cetakan Pertama, Jakarta: Gema Insani, http://www.gemainsani.co.id, gipnet@indosat.net.id. , 2007, The Islamic Vision of Development in the Light of Maqasid Al-Shariah, Islamic Research and Training Institute, Islamic Development Bank, Jeddah.

Chorafas, Dimitris, 2000, Managing Credit Risk. Analysing, Rating and Pricing The Probability of Default, Euromoney Books, Nestor House, Playhouse Yard, London EC4V 5EX.

Choudhury, Masudul Alam, 1997, Money in Islam, A Study in Islamic Political Economy, Routledge, London and New York.

Cihak, Martin. Heiko Hesse, 2008, Islamic Banks and Financial Stability: An Empirical Analysis, IMF Working Paper, International Monetary Fund, http://www.imf.org/external/pubs/ft/wp/2008/wp018.pdf.

DiVanna, Joseph A., 2008, Understanding Islamic Banking, The Value Proposition That Transcends Cultures, Cambridge, United Kingdom: Leonardo and Francis Press, ltd.

Dobson, John, 1999, Is Shareholder Wealth Maximation Immoral ? Financial Analysts Journal, Sept/Oct 1999; 55, 5; ABI/INFORM Global.

Ebrahim, M. Shahid. Tan Kai Joo, 2001, Islamic Banking in Brunei Darussalam, International Journal of Social Economics, Vol. 28, Ko 4, pp 314-337, MCM University Press. http://www.emerald-library.com/ft.

Eko Suprayitno, 2005, Ekonomi Islam, Pendekatan Ekonomi Makro Islam dan Konvensional, Yogyakarta: Penerbit Graha Ilmu.

El-Diwany, Tarek, Juni 2003, The Problem with Interest, Sistem Bunga dan Permasalahannya, Cetakan Pertama, Akbar Media Eka Sarana, Jakarta, akmed@cbn.net.id 
Ellsworth, Richard R.,2010, Tujuan Perusahaan, In Craig L. Pearce, Joseph A. Marciariello, dan Hideki Yamawaki, Drucker Difference, Jakarta: Ufuk Press.

Errico, Luca. Mitra Farahbaksh, 1998, Islamic Banking: Issues in Prudential Regulation and Supervision, IMF Working Paper, WP/98/30, leriico@imf.org, mfarahbaksh@imf.org.

Fukuyama, Francis, 1996, Trust, The Social Virtues and The Creation of Prosperity, Copyright (C) 1995 by Francis Fukuyama, First Free Press Paperback Edition 1996, Simon \& Schuter Inc., New York.

Gait, A. A. C. Worthington, 2007, A Primer on Islamic Finance: Definitions, Sources, Principles and Methods, Faculty of Commerce-Papers, University of Wollongong, http://www.scribd.com/doc/8027728/Aprimer-on-Islamic-finances-sources-principles-andmethods.

Green, Stephen, 2009, Good Value, Reflection on Money, Morality, and Uncertain World London: Alan Lane, Penguin Books.

Gymnastiar, Abdullah, Hermawan Kartajaya, 2004, Berbisnis dengan Hati, Jakarta: MarkPlus \& Co.

Honohan, Patrick, 2001, Islamic Financial Intermediation: Economic and Prudential Considerations, Development Reseach Group and Financial Sector Strategy and Policy Department, The World Bank.

Iqbal, Zamir. Abbas Mirakhor, 2007, An Introduction to Islamic Finance, Theory and Practice, Singapore: John Wiley \& Sons (Asia) Pte Ltd.

Kamali, Mohammad Hashim, 2006, Equity and Fairness in Islam, The Islamic Texts Society, Cambridge U.K., Kuala Lumpur: Ilmiah Publishers.

Lewis, Hunter, 2009, Where Keynes Went Wrong, And Why World Governments Keep Creating Inflation, Bubbles, and Busts, Axios Press, Mount Jackson, VA.

Lobo, Isobel, Frank Bonello, 2005, Islamic Banking Meets "Conventional" Banking: A Survey of Recent Developments in Banking In Pakistan, AIBSE (USA) 2005 Annual Meeting, Charleston, SC. www.aibse.org/Proceedings/../Islamic\%20banking.doc.

Mankiw, N. Gregory, Teori Ekonomi Makro, Jakarta: Penerbit Salemba Empat, 2004.

Marthon, Said Saad, 2004, Ekonomi Islam, di Tengah Krisis Ekonomi Global, Jakarta: Zikrul Hakim.

Masood Khan, Waqar, 2006, Transition To A Riba Free Economy, New Delhi: Adam Publishers \& Distributors, apd@ bol.net.in, adam2@sify.com. 
Masyuri, 2005, Teori Ekonomi Dalam Islam, Yogyakarta: Kreasi Wacana.

Millet, Paul, 2002, Lending and Borrowing in Ancient Athens, Cambridge, United Kingdom: Cambridge University Press.

Morris, Charles R., 2008, The Two Trillion Dollar Meltdown, Easy Money, High Rollers, and The Great Credit Crash, New York: PublicAffairs.

Muldrew, Craig, 1998, The Economy of Obligation, The Culture of Credit and Social Relations in Early Modern England., New York: Palgrave.

Mufid, Sofyan Anwar, 2010, Islam \& Ekologi Manusia, Bandung: Nuansa.

Muldrew, Craig, 1998, The Economy of Obligation, The Culture of Credit and Social Relations in Early Modern England. Palgrave, Houndmills, Basingstoke, Hampshire RG21 6XS and 175 Fifth Avenue, New York, NY 10010.

Muthahhari, Ayatullah Murtadha, 2011, Islam \& Tantangan Zaman, Jakarta: Sadra International Institute.

Nagaoka, Shinsuke, 2009, Reconsidering Mudaraba Contracts in Islamic Finance: What is the Economic Wisdom (Hikma) of Partnership-based Instruments? Kyoto Working papers on Area Studies No. 42 (G-COE Series 40).

http://www.humanosphere.cseas.kyoto.u.ac.jp/images/libraryimage/work ingpaper/40_nagaoka.pdf.

Nakamura, Leonard I, 1991, Lessons on Lending and Borrowing in Hard Times, Business Review-Federal reserve Bank of Philadelphia, July/August 1991; ABI/INFORM Global.

Nawawi, Razali HJ., 2009, Islamic Law on Commercial Transaction, Kuala Lumpur: CERT Publications.

Nik Mohamed Affandi Bin Nik Yusoff, 2002, Islam \& Buisness, Selangor: Publications (M) Sdn Bhd.

Orgianus, Yan, 2012, Moralitas Islam Dalam Ekonomi \& Bisnis, Bandung: Marja.

O'Hara, Kieron, 2004, Trust from Socrates to Spin, Cambridge, United Kingdom: Icon Books.

Qardhawi, Yusuf, 1997, Norma dan Etika Ekonomi Islam. Jakarta: Gema Insani Press.

Rivai, Veithzal, Adria Permata Veithzal, 2008, Islamic Financial Management, Teori, Konsep, dan Aplikasi Panduan Praktis untuk Lembaga Keuangan, Nasabah, Praktisi, dan Mahasiswa, Jakarta: RajaGrafindo Persada. 
Rosly, Saiful Azhar, 2005, Critical Issues on Islamic Banking and Financial Markets, Kuala Lumpur, Malaysia: Dinamas Publishing, drsaifu199@ hotmail.co.

Saeed, Abdullah, 2004b, Bank Islam dan Bunga, Studi Kritis dan Interpretasi Kontemporer Tentang Riba dan Bunga, Yogyakarta: Pustaka Pelajar, pustakapelajar@telkom.net.

, 2004, Menyoal Bank Syariah, Kritik atas Interpretasi Bunga Bank, Kaum Neo Revivalis, Jakarta: Paramadina.

Marthon, Said Sa'ad, 2004, Ekonomi Islam Di Tengah Krisis Ekonomi Global, Jakarta:

Shakespeare, Rodney, 2007, The Modern Universal Paradigm, Jakarta: LPFE Trisakti.

Shaw, Robert Bruce, 1997, Trust in Balance, Building Successful Organizations on Results, Intergrity and Concern, San Fransisco, California: Jossey Bass Inc.

Shihab, Quraish, 2012, Al Lubab, Makna, Tujuan, dan Pelajaran dari SurahSurah Alqur'an, Tangerang: Lentera Hati. , 2013, Secercah Cahaya Ilahi, Hidup Bersama Alqur'an, Bandung: Mizan.

Shihab, Umar, 2008, Kontekstualitas Alqur'an, Jakarta: Penamadani.

Shirazi, Habib, 1988, Islamic Banking Contracts, Publication No. 6, Banking Training Center, Central Bank of The Islamic republic of Iran, Teheran.

Siddiqi, Mohammad Nejatullah, 2006, Islamic Banking and Finance Theory and Practice: A Survey of State of the Art, Islamic Economic Studies, Vol. 13, No. 2, February, 2006.

Sofyan S. Harahap, Pelajaran dari Krisis Asia, Jakarta: Pustaka Quantum, 2002.

Toutounchian, Iraj, 2009, Islamic Money \& Banking, Integrating Money in Capital Theory, Singapore: John Wiley \& Sons (Asia) Pte.Ltd.

Usmani, Muhammad Taqi, 2005, An Introduction to Islamic Finance, Karachi, Pakistan: Maktaba Ma'ariful Qur'an.

Vogel, Frank E. Samuel L. Hayes III, 1998, Islamic Law and Finance, Religion, Risk and Return, London: Kluwer Law International.

Warde, Ibrahim, 2001, Islamic Finance in the Global Economy, Edinburg University Press, Edinburg, Great Britain.

Zarqa, Muhammad Anas, May 1997, "Istisna" Financing of Infrastructure Projects”, Islamic Economic Studies, Vol. 4, No. 2. 